\title{
Upscaling Nitrogen Removal Capacity from Local Hotspots to Low Stream Orders' Drainage Basins
}

\author{
Gilles Pinay, ${ }^{1 *}$ Stefan Peiffer, ${ }^{2}$ Jean-Raynald De Dreuzy, ${ }^{3}$ Stefan Krause, ${ }^{4}$ \\ David M. Hannah, ${ }^{4}$ Jan H. Fleckenstein, ${ }^{5}$ Mathieu Sebilo, ${ }^{6}$ Kevin Bishop, ${ }^{7}$ \\ and Laurence Hubert-Moy ${ }^{8}$
}

\begin{abstract}
${ }^{1}$ CNRS - OSUR - ECOBIO, University Rennes 1, Campus de Beaulieu, Avenue du Général Leclerc, 35042 Rennes Cedex, France; ${ }^{2}$ BayCEER, Department of Hydrology, University of Bayreuth, 95440 Bayreuth, Germany; ${ }^{3}$ CNRS - OSUR - GEOSCIENCES Rennes, University Rennes 1, Campus de Beaulieu, Avenue du Général Leclerc, 35042 Rennes Cedex, France; ${ }^{4}$ School of Geography, Earth and Environmental Sciences, University of Birmingham, Edgebaston, Birmingham B15 2TT, UK; ${ }^{5}$ Department of Hydrogeology, Helmholtz Center for Environmental Research - UFZ, Permoserstr. 15, 04318 Leipzig, Germany; ${ }^{6}$ Sorbonne Universités, UPMC Univ Paris 06, CNRS, 4 Place Jussieu, 75005 Paris, France; ${ }^{7}$ Institutionen för Vatten Och Miljö, Lennart Hjelms väg 9, Box 7050, 750 07 Uppsala, Sweden; ${ }^{8}$ COSTEL-LETG, University Rennes 2, Campus Villejean, Place du Recteur Henri Le Moal, CS 24307, 35043 Rennes Cedex,
\end{abstract} France

\begin{abstract}
Denitrification is the main process removing nitrate in river drainage basins and buffer input from agricultural land and limits aquatic ecosystem pollution. However, the identification of denitrification hotspots (for example, riparian zones), their role in a landscape context and the evolution of their overall removal capacity at the drainage basin scale are still challenging. The main approaches used (that is, mass balance method, denitrification proxies, and potential wetted areas) suffer from methodological drawbacks. We review these approaches and the key frameworks that have been proposed to date to formalize the understanding of the mechanisms driving denitrification: (i) Diffusion versus advection pathways of nitrate transfer, (ii) the biogeochemical hotspot, and (iii) the Damköhler ratio. Based on these frameworks, we propose to use high-resolution mapping of catch-
\end{abstract}

ment topography and landscape pattern to define both potential denitrification sites and the dynamic hydrologic modeling at a similar spatial scale $\left(<10 \mathrm{~km}^{2}\right)$. It would allow the quantification of cumulative denitrification activity at the small catchment scale, using spatially distributed Damköhler and Peclet numbers and biogeochemical proxies. Integration of existing frameworks with new tools and methods offers the potential for significant breakthroughs in the quantification and modeling of denitrification in small drainage basins. This can provide a basis for improved protection and restoration of surface water and groundwater quality.

Key words: denitrification; biogeochemical hotspot; upscaling; residence time distribution; Damköhler ratio; diffuse pollution control.
Received 12 June 2014; accepted 7 March 2015; published online 5 May 2015

Author contribution GP proposed the structure of the paper and wrote it in collaboration with SP, JRD, SK, DMH, JF, MS, KB, and LHM who contributed to the writing of the paper.

*Corresponding author; e-mail: gilles.pinay@univ-rennesl.fr

\section{INTRODUCTION}

Wide application of industrially produced nitrogen fertilizer for agriculture has contributed preeminently to the doubling of nitrogen fluxes over the last 60 years (Galloway and others 2008). The 
quantification and management of nitrogen leaching from agricultural land remain as the main challenges because of diffuse transport pathways to water bodies (Alexander and others 2000). Indeed, the doubling of reactive nitrogen has tremendous direct effects on surface water eutrophication in lakes and streams as well as in estuarine (for example, Brittany) and marine (for example, North Sea and Baltic) environments. These environmental impacts led Rockstrom and others (2009) to consider this nitrogen increase as one of the two most pressing global environmental concerns together with the loss of biodiversity (Seitzinger 1988; Vitousek and others 1997; Seitzinger and others 2006; Diaz and Rosenberg 2008; Galloway and others 2008).

Estimations of nitrogen removal capacity based on budget balances have reported that about 30 to $40 \%$ of $N$ input in river catchments is lost by denitrification (Seitzinger and others 2006): the microbially facilitated reduction of nitrate and other nitrogen oxides to dinitrogen. This microbial process uses nitrate as an electron acceptor during the oxidation of the organic matter (the electron donor). Denitrification is a well-known pathway and its proximal primary environmental drivers (that is, anoxia, presence of bioavailable organic carbon, and in situ nitrate concentrations) are well defined. Yet, direct measurement of in situ denitrification is very difficult due to the high spatio-temporal variability of its environmental drivers (Groffman and others 2006).

It has been known for several decades that denitrification is the main process removing nitrate in riparian zones, which can buffer upslope input of nitrate and limit aquatic ecosystem pollution (see reviews by Burt and others 2010; Ranalli and Macalady 2010). These particular landscape features possess all the characteristics to potentially host denitrification activity, that is, (i) anoxia in soil during stream flood events or groundwater rise, (ii) the presence of high organic matter concentration in soils generated by very productive riparian vegetation, and (iii) the potential nitrate input from surface and subsurface flow from adjacent agricultural lands (see review by Décamps and others 2004). Many case studies have been conducted during the last 30 years that confirmed the potential nitrogen buffering capacity of riparian zones and have reported removal rates of up to $90 \%$ (for example, Vidon and Hill 2004a). But these studies have also underlined substantial spatial variability caused by local geomorphic heterogeneity (Sabater and others 2003), local hydrogeological conditions (Vidon and Hill 2004a, b; Duval and Hill 2006), and temporal variability caused by stochastic groundwater table fluctuations and flood events (Burt and others 2002) or stream stage fluctuations. The large local variability in nitrogen buffering capacity makes robust extrapolation of site-specific nitrogen retention to the landscape and/or drainage basin level, a major research challenge. Similar challenges are faced in understanding the role of the riparian zone for other substances, including DOC (Grabs and others 2012). Model-based estimations of the potential riparian nitrate removal capacity under optimal conditions for denitrification to operate reveal that riparian zones could not contribute more than $15-20 \%$ of the removal of total nitrogen fluxes in agricultural catchments (Groffman and others 2006; Montreuil and Mérot 2006; Seitzinger and others 2006). Indeed, riparian zones are not the only landscape features in which nitrogen is removed very efficiently by denitrification. For instance, hyporheic zones (Hill and others 1998; Duval and Hill 2006; Krause and others 2009, 2013; Trauth and others 2014), ditches, potholes, upland slope breaks (Clément and others 2003), hedgerows (Viaud and others 2001), are other landscape structures that can promote microbial denitrification, at least seasonally. Knowledge about the extent of their contribution to overall nitrate turnover is critical for management. However, the identification of these hotspots and their role in a landscape context (Vidon and others 2010) requires further research to evaluate the overall removal capacity of these landscape features mentioned above at the drainage basin scale.

\section{ExISTINg Approaches}

\section{Mass Balance Method}

It consists of comparing nitrogen input within the catchment with nitrogen output at the outlet from the drainage basin. Since Omernik's studies (1976), several nitrogen input-output studies in large drainage basins, that is, greater than $500 \mathrm{~km}^{2}$, have shown a positive relationship between the percentage of agricultural land and fluxes of nitrogen at the outlet. The European Water Framework Directive (EU 2000), which stipulates monthly measurement of nitrate concentration at least in drainage basins of $100 \mathrm{~km}^{2}$ or larger promotes such an approach. The interpretation of such relationships in these mass balance approaches is difficult because it is based on a black-box approach, which does not provide much information on the actual removal capacity of the specific landscape features within the wider drainage basin. In fact, denitrifi- 
cation is simply estimated as the difference between nitrogen input and output (Groffman and others 2006; Seitzinger and others 2006) and does not provide a suitable spatio-temporal framework.

\section{Proxies of Denitrification}

These proxies include potential denitrification activity and potential wetted area, measured by biogeochemical and geographic methods, respectively, to quantify the spatio-temporal variability of denitrification. Potential denitrification activity (for a review of methods see Smith and Tiedje 1979; Burt and others 2010) provides a useful indication of the denitrifying enzyme activity present at the sampling time. Potential denitrification can reflect immediate environmental changes affecting denitrification activity such as soil moisture and aeration, for instance. It provides also an evaluation of the potential physiological denitrification capacity of the existing denitrifying community; as such it represents a more robust picture of current environmental conditions. Yet, in the past, several studies have over-interpreted the results of this method by confounding potential and actual denitrification activity. Indeed, potential denitrification can provide information on the potential ability of the existing community but not on the real rates because they also depend on the nitrate availability/input to the site which is primarily influenced by the local hydrogeological context (Sabater and others 2003).

At the drainage basin scale, potentially wetted areas or wetlands, where anoxic conditions and organic carbon accumulation prevail, have been often used as proxy for denitrification. Several types of models based on topographic indices, that is, the upslope contributing area per unit contour and the local slope angle (Beven and Kirkby 1979; Moussa 2009) have been used to evaluate the areal extent of potentially wetted areas within a drainage basin (Mérot and others 2003). This modeling approach is very useful for quantifying the potential for wetlands to develop within catchments (Poggio and Soille 2011). Although this approach provides a qualitative indicator for potential denitrification zones, it does not support any quantitative assumptions of nitrogen removal because it does not provide information about nitrate input or residence time. Indeed, coincidence of flow paths transporting nitrate into reactive anoxic zones are a prerequisite for denitrification to occur (McClain and others 2003). Several attempts to use a hydrogeomorphic unit approach based on Brinson and others' work (1984) did not really improve our capacity to assess denitrification rates because of the lack of the hydrological component necessary to quantify nitrate input to the anoxic sites. Moreover, residence times of water in soils or sediments need to be quantified to move from potential denitrification zones to actual ones. Indeed, several in situ studies have demonstrated that increasing the time water resides within sediment or soil increased nitrogen retention and removal (Pinay and others 2002, 2007; Zarnetske and others 2011). It may seem surprising in a world where the nitrogen fluxes have doubled over the last 60 years, but in most cases, the key limiting factors for denitrification are (i) the nitrate input to the active sites and (ii) the time a nitrate molecule is being exposed to denitrifying conditions, that is, its exposure time (Oldham and others 2013). Hence, the local hydrogeological context is the key denitrification driver (Sabater and others 2003). Therefore, the move from potential denitrification to real denitrification activity evaluation at the drainage basin level requires the quantification of nitrate input into these potential denitrification sites (McClain and others 2003). At the landscape scale, the riparian buffer ratio as defined by McGlynn and Seibert (2003) in the hydrological landscape analysis, or the length of contact between dry and wet areas, including upslope/wetland lengths, should be a good proxy for nitrate input to a potential denitrification site. Indeed, many studies on the role of riparian zones in mitigating diffuse nitrate pollution revealed that when removal occurred, it was within the first few meters of the riparian zone seen from the upslope side (Clément and others 2003; Sabater and others 2003). The advantage of such a proxy is that it can include other types of wet/dry interfaces and can be easily quantified at large scales using remote sensing imagery.

\section{Hydrologic Landscape Analysis}

Hillslope hydrology is predominantly controlled by topography in catchments with shallow soil and poorly permeable bedrock, which are typical for some regions. McGlynn and Seibert (2003) examined the variability in, and controls on, hillslope inputs to stream networks and the potential for riparian zones to regulate hillslope inputs and thereby both quantitatively and qualitatively buffer, or modify, stream responses to hillslope hydrology. The ratio of riparian zone storage to hillslope inputs was the most important plot-scale measure of the buffering capacity of the riparian zone. Clearly, catchments will differ in the degree to 
which riparian zones buffer the delivery of water from hillslopes to streams, thereby affecting the amount, timing, and quality of hillslope water inputs expressed in streamflow (McGlynn and others 1999; McGlynn and McDonnell 2003). Hydrologic dynamics within and connections between landscape units partially control the sources, flowpaths, amount, and age of water exiting the catchment through each segment of the riparian zone. Each landscape unit type has characteristic hydrologic and geomorphic attributes that can be assessed through field investigations and topographic analysis of emergent patterns and connections between landscape units (landscape organization). For instance, Meybeck and Moatar (2012) propose a typology of catchment nutrient transfer responses based on relationships between the log of nutrient concentration and log of discharge, as well as flux estimations and their uncertainties (Moatar and others 2013). Hydrological landscape analysis (HLA) techniques enable such upscaling as demonstrated in a diverse variety of catchments in published research. HLA can, for instance, provide a quantification of the topographic control on water age or residence time distributions. Often it is expected that mean water age in runoff increases with catchment area but this could not be confirmed by either McGlynn and others (2004, 2005). McGlynn and others (2004) found the median subcatchment area to be correlated with mean residence time, whereas McGuire and others (2005) found the median flowpath length toward the stream network divided by its gradient to be best correlated with residence times. Duncan and others (2013) used HLA, in combination with local field measurements of $\mathrm{N}_{2}$ gas production, as a proxy for denitrification to upscale denitrification to a whole forested catchment. They found that denitrification hotspots in topographic hollows caused by riparian microtopography, as shown earlier by Frei and others (2012), has a significant influence on catchmentscale denitrification.

\section{Model-Based Upscaling of Local Nitrate Removal Capacities}

Deterministic, spatially detailed catchment models (for example, SWAT (Arnold and others 1998), SWIM (Krysanova and others 1998), INCA (Whitehead and others 1998), HBV-N (Arheimer and Brandt 1998) are applied at large-scale drainage basins (up to several $100,000 \mathrm{~km}^{2}$ ) to quantify nitrogen uptake and removal in a spatially distributed way (Sahu and Gu 2009; Lam and others 2010; Ficklin and others 2013; Poudel and others 2013).
Yet, the spatial and temporal heterogeneities of the denitrification process in particular in riparian corridors, characterized by the spatially and temporally dynamic exchange between groundwater and surface water question their large-scale assessment reliability. As these models are designed to assess water quality at the scale of entire catchments, their underlying concepts are based on significant spatial averaging of catchment properties (for example, at the subcatchment scale) and processes (that is, they are semi-distributed) and simplified descriptions of the connected groundwater system (for example, INCA, SWAT). Furthermore, system dynamics are averaged in time by typically using relatively long time steps. Similarly, the spatial discretization of mesoscale catchment models such as SWAT or SWIM is organized in terms of hydrological response units (HRU's) that are assumed to represent homogeneous landscape units of similar hydrological behavior. As model discretization and delineation of response units at large scales are considered to be static, the behavior at interface zones such as riparian corridors and wetlands (Hattermann and others 2006) are usually not implemented in a dynamic way. Due to these limitations such models are usually applied for predicting average system behavior (for example, monthly or annual loads over longer time periods) and frequently assess the impacts of climate and land-use changes, but are limited in their capacity to represent dynamic feedback functions at interfaces such as riparian zones, which would be needed, for example, to evaluate local measures to improve water quality. Process-rate variability leads to lack of precision in such models. Moreover, bias in denitrification estimation often arises when there is co-variation between denitrification activity in the riparian zone and nitrogen inputs from upslope soils to these riparian zones. This bias leads to serious inaccuracies.

\section{The Existing Frameworks}

Three main frameworks have been proposed to date to formalize the understanding of the forces driving denitrification and the upscaling of nitrogen removal capacity to the landscape and drainage basin organization levels (Figures 1, 2, 3). These three frameworks, that is, the classification of denitrification areas according to whether nitrate transfer is via diffusion or advection (Seitzinger and others 2006), the "biogeochemical hot spot" concept (McClain and others 2003), and the application of the Damkhöler ratio to evaluate riparian zone nitrogen removal efficiency (Ocampo and others 2006), provide complementary elements to 
evaluate nitrogen removal capacity in drainage basins.

\section{Diffusion Versus Advection}

In a review paper, Seitzinger and others (2006) classified sites along a continuum ranging from terrestrial to freshwater and marine environment as a function of the nitrate delivery mode to the denitrification zone. The classification of sites as a function of the delivery of nitrate, that is, by diffusion or advection, can be related to particular types of landscape/waterscape features (Figure 1). For instance, lake and pond sediments can be classified as zones where nitrate is delivered to the denitrification areas mostly by diffusion, whereas riparian or hyporheic zones are mostly characterized by a nitrate delivery by advection. The diffusion/advection framework touches upon the rate of delivery of nitrate, and as such, adds a temporal component. Indeed, diffusion rate is often slower than denitrification rate measured in lakes, pond, or stream sediments (Sébilo and others 2003). In such cases, the rate of nitrate delivery is the limiting factor for denitrification. On the contrary, nitrate advection can present a wide range of delivery rates, depending on factors driving the local water flow rate, that is, slope, matrix structure and texture, hydraulic conductivity. Therefore, in the advection case, either nitrate delivery or rate of activity of the denitrifiers can be the limiting factor for denitrification (Sébilo and others 2003).

Apparently, the time that is available for denitrification is completely different for the two cases. It therefore seems appropriate to define characteristic time scales at which either the advective or the diffusive system is being exposed to conditions favorable for denitrifying activities (Oldham and others 2013). Appropriate conditions for denitrification imply anoxic conditions.

Under advective delivery mode the exposure time to anoxic conditions, $\tau_{E, \text { anoxic }}^{\text {adv }}$ is defined as

$$
\tau_{E, \text { anoxic }}^{\mathrm{adv}}=\frac{L_{\mathrm{anoxic}}}{v}
$$

$\tau_{E, \text { anoxic }}^{\mathrm{adv}}$ is a mean value and there is a probability distribution attached to it, where $L_{\text {anoxic }}$ is the length scale over which transport processes are operating under anoxic conditions $(\mathrm{m}), v$ is the mean ground water flow velocity (for example, in $\mathrm{m} \mathrm{d}^{-1}$ ).

Alternatively, the exposure time scale to anoxia under diffusive conditions is given as

$$
\tau_{E, \text { anoxic }}^{\text {diff }}=\frac{\left(L_{\text {diff }}\right)^{2}}{D_{\text {eff }}},
$$

$D_{\text {eff }}$ is the effective diffusion coefficient $\left[\mathrm{m}^{2} \mathrm{~s}^{-1}\right]$ and $L_{\text {diff }}[\mathrm{m}]$ is the length scale of the system across which diffusion occurs.

Putting this concept into a more quantitative framework, diffusion versus advection can be addressed in terms of the Peclet number under the assumption of identical advection and diffusion scales $\left(L_{\text {diff }}=L_{\text {anoxic }}\right)$ (Oldham and others 2013). The non-dimensional Peclet number, $P e$, provides the balance between advection and diffusion under hydrological connectivity, as

$$
P e=\frac{\tau_{E, \text { anoxic }}^{\text {diff }}}{\tau_{E, \text { anoxic }}^{\text {adv }}}=\frac{v \cdot L_{\text {anoxic }}}{D_{\text {eff }}} .
$$

Typically, $P e$ numbers $\gg 1$ are indicative of relatively slower diffusion than advection and thus advective transport, while $P e$ numbers $\ll 1$ reflect relatively slower advection to diffusion and thus diffusive transport. Critical zones in terms of transport are systems where $P e$ is on the order of 1 . Here diffusive mixing becomes relevant. Note that $\mathrm{Pe}$ balances with scale, that is, the smaller the scale the more the systems tend to become diffusion controlled.

At small scales, diffusion is a very efficient mixing process that tends to homogenize concentrations. With classical values of diffusion coefficients for nitrate in water of $210^{-9} \mathrm{~m}^{2} / \mathrm{s}$, the typical dif-
A

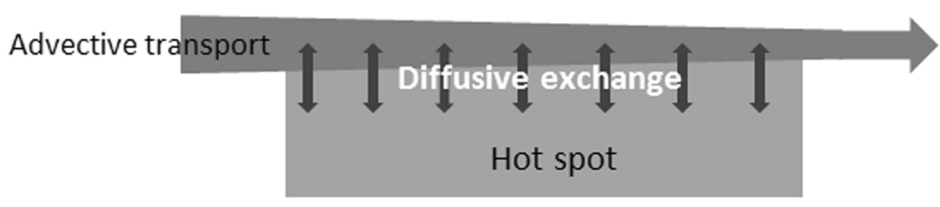

B

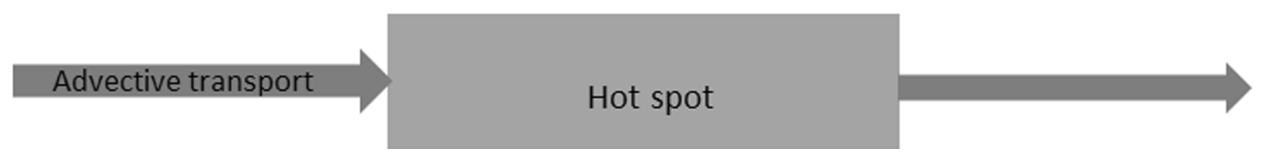

Figure 1. Schematic representation of the existing frameworks related to denitrification appraisal. A Diffusion of nitrate into the denitrification hotspot (for example, pond or lake sediment) or $\mathbf{B}$ advection (for example, riparian or hyporheic zone). 
fusion times across pores of $100 \mu \mathrm{m}$ to $1 \mathrm{~mm}$ are of the order of $5 \mathrm{~s}$ to $8 \mathrm{~min}$. Advection transports solutes over long distances more quickly delivering them to potential turnover sites where diffusion can mix them with other reactants.

The characteristic mixing scale is much enlarged by hydrodynamic dispersion processes (Bear 1973). Hydrodynamic dispersion comes from the porescale and interpore-scale velocity fluctuations and is generally modeled as an effective diffusion process under Fick's law. The equivalent dispersion coefficient $D$ is proportional to the velocity $v$ and to the dispersivity $\alpha$. Taking the Peclet number with respect to dispersion rather than to diffusion leads to $P e=L_{\text {anoxic }} / \alpha$. The Peclet number can also be interpreted as the ratio of the characteristic advection scale to the dispersivity (characteristic dispersion scale). As dispersivity ranges from centimeters to hundreds of meters depending on the geological material and of the scale itself (Gelhar and others 1992), the critical scale over which mixing equilibrates with transport is much larger than the pore scale and can reach meters to decameters.

\section{Biogeochemical Hotspot}

The second framework is the biogeochemical hotspot concept (Figure 2). It stipulates that biogeochemical hotspots are "areas (or patches) that show disproportionately high reaction rates relative to the surrounding area (or matrix)" (McClain and others 2003). These hotspots occur at the convergence of hydrological flowpaths carrying complementary reactants, or where a flowpath carries one reactant into a substrate containing the other reactant. The convergence of reactants can be found, for instance, in stream hyporheic zones where nitrate transported by groundwater upwelling merges with organic carbon provided by surface water down-welling into the hyporheic zone (Krause and others 2009, 2013; Trauth and others 2014). Nitrate being transported by surface or subsurface flow into the riparian zone represents the second case, that is, the nitrate reactant being carried into a zone where the other conditions necessary for denitrification (availability of organic carbon and anoxia) are present. Current hyporheic zone modeling approaches focus on a hydrologically controlled spatial extent of the hyporheic zone, but with few exceptions (Zarnetske 2011; Bardini and others 2012; Trauth and others 2014), do not take into account that electron donors and acceptors might be delivered via different pathways. Hence, from a kinetic point of view, biogeochemical hotspots are zones where turnover rates are high and can be characterized by short characteristic reaction time scales $\tau_{\text {reaction. }}$ Characteristic reaction time scales can be derived from any kinetic rate law as the time that is required to establish a certain turnover rate. The most common approach is to use the inverse of the first-order rate intrinsic constant $k$ [for example, $1 / d]$, that is, $\tau_{\text {reaction }}=1 / k$.

The rate constant is the intrinsic constant valid at the molecular scale or the scale at which microbes are operating. This rate constant is scale invariant and should not be confounded with effective rate constants derived from fitting, for example, of the advection dispersion equation with a reaction term calculated from slurry experiments.

\section{Damköhler Number}

The third framework is related to the evaluation of the nitrate removal efficiency of riparian zones using the Damköhler number (Figure 3). The dimensionless Damköhler number is the ratio between the rate of transport (rate of nitrate input to the site) and the rate of reaction (denitrification in the site). This can be defined as the ratio between the exposure time to anoxic conditions and the reaction time scale of nitrate:

$$
D a_{\mathrm{NO}_{3}^{-}}=\frac{\tau_{E, \text { anoxic }}}{\tau_{\text {reaction }}}
$$

Thus, it is a measure of the competition between transport and reaction processes and it actually combines the two frameworks discussed above. Large Damköhler ratios
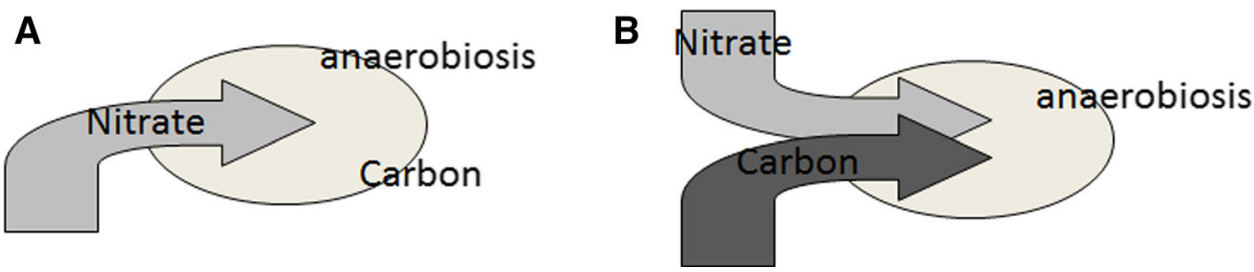

Figure 2. Schematic representation of the existing frameworks related to denitrification appraisal. The hotspot concept with $\mathbf{A}$ input of nitrate into the denitrification hotspot (for example, riparian zone), and $\mathbf{B}$ convergence of nitrate and organic carbon into the denitrification hotspot (for example, hyporheic zone). Adapted from McClain and others (2003). 


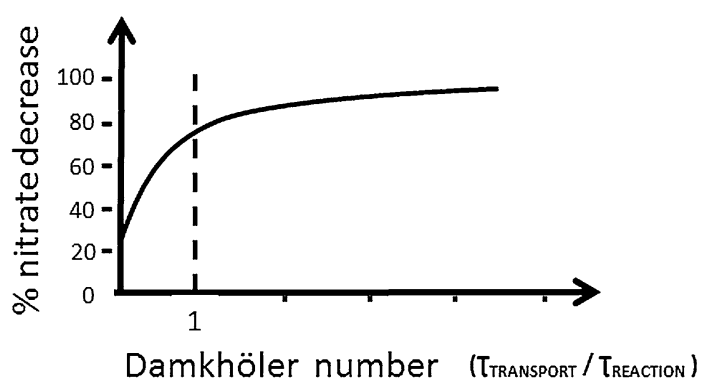

Figure 3. The Damkhöler number as a function of nitrate buffer zone capacity of potential denitrification hotspots. Adapted from Ocampo and others (2006).

$\left(D a_{\mathrm{NO}_{3}^{-}} \gg 1\right)$ indicate reaction times much smaller than exposure times to anoxic conditions. The reaction has ample time to occur within the allocated exposure time and nitrate is efficiently removed. On the contrary, when the characteristic reaction time is much larger than the characteristic exposure time $\left(D a_{\mathrm{NO}_{3}^{-}} \ll 1\right)$, the reaction does not have time to occur and nitrate is not removed.

Ocampo and others (2006) used the Damköhler number to quantify the relative importance of transport versus reaction in the attenuation of nitrate concentrations within riparian zones. Their study was based on published results from several sites all over the world. They predicted an increase in nitrate removal rate $R_{\mathrm{NO}_{3}}$ from riparian zones with increasing Damköhler numbers. We have evaluated their data and obtained an exponential relationship between these two variables.

$$
R_{\mathrm{NO}_{3}}[\%]=75 \cdot(1-\exp (-0.4 D a))-25 .
$$

Marzadri and others (2012), Zarnetske and others (2012a, b), and Briggs and others (2013) used a similar approach based on a Damköhler number for oxygen consumption to delineate zones of net denitrification from zones of net nitrification in the hyporheic zone.

These three frameworks are very complementary in their quest to appraise the overall denitrification activity or nitrate removal in landscapes and drainage basins; but none of them fully reached that goal, because of the daunting challenge of upscaling heterogeneous processes both in space and time (Groffman and others 2006). Yet, identification of potential biogeochemical hotspots, modes of local delivery, that is, diffusion versus advection and transport rate versus activity rate provide a sound basis for building up a new approach.

$\mathrm{Gu}$ and others (2007) have highlighted the interdependence of $P e$ and $D a$ because inherent to $D a$ numbers is also the flow rate. Nitrate removal rates are at a minimum for both low $\mathrm{Pe}$ and low $\mathrm{Da}$, whereas they are at their maximum rates for $P e$ values greater than 10 and $D a$ greater than 25 in their example. The effect of flow rate has an opposite effect on both numbers. For a given reaction time scale, removal rates are decreasing if the flow rates are too high (exposure time should be too short, $D a$ number decreasing) but on the other hand, $P e$ numbers are increasing. Hence a combination of low turnover rate, low $P e$ (diffusive conditions), and low $\mathrm{Da}$ can only be achieved if the characteristic reaction time is low.

\section{Toward AN InTEgration OF FramewOrKs}

We propose to combine the concepts of residence time distribution (RTD) and $\mathrm{Da} / \mathrm{Pe}$ relationships, which are strongly interdependent. Pore to Darcy scale hydrodynamic dispersion progressively transforms the Dirac distribution into more complex distributions, which span a large range of residence times, as described for example, by an exponential, power law or inverse Gaussian distribution (Table 1) (Bear 1973). Figure 4 presents the differences between the well-peaked Dirac distribution (blue) and the more extended exponential and inverse Gaussian distributions (red and black).

This requires tools for determining RTD in anoxic zones and also the spatial and temporal variability of $\mathrm{Da}$ and $\mathrm{Pe}$. Both $\mathrm{Da}$ and $\mathrm{Pe}$ are functions of RTDs, that is, hydrological functions ( $D a$ via the exposure time and $P e$ via the ratio between advective and diffusive transport). But $D a$ is also a function of the characteristic reaction time, that is, of biogeochemical functions. For kinetically controlled reactivity, it can be compared even more straightforwardly to the characteristic reaction time, or even to some distributed first-order reaction times if needed, by convolution of exposure time and reaction time distributions. For this, it is critical to define the intrinsic rate constants, their dependence on electron donors (that is, DOC), and their spatial variation (various species).

Table 1. Probability Distribution Functions Derived for the Damköhler Number Directly Derived from the Residence Time Distributions with Parameters $\mu$ for the Mean Damköhler Number and $P e$ for the Peclet Number if Relevant as Illustrated in Figure 5

\begin{tabular}{ll}
\hline Distribution & Probability density function \\
\hline Dirac & $p(D a)=\delta(D a-\mu)$ \\
Exponential & $p(D a)=\frac{1}{\mu} \exp \left(-\frac{D a}{\mu}\right)$ \\
Inverse Gaussian & $p(D a)=\frac{1}{\mu}\left(\frac{P e}{4 \pi(D a / \mu)^{3}}\right) \exp \left(-\frac{(1-D a / \mu)^{2}}{4 P e(D a / \mu)}\right)$ \\
\hline
\end{tabular}


In hot-spots environments where bioavailable organic matter exists in excess, for example, peatlands, wetlands, and relict $\mathrm{C}$ deposits (Gurwick and others 2008), denitrification can be approximated to be a pseudo zero-order reaction with respect to organic matter (Reddy and Patrick 1984), which implies that

$$
\frac{d c\left(\mathrm{NO}_{3}^{-}\right)}{d t}=-k^{\prime} c\left(\mathrm{NO}_{3}^{-}\right)
$$

where $k^{\prime}$ combines the 2 nd order rate constant for denitrification $k_{\text {den }}$ and the concentration of dissolved organic matter. Reddy and others (1982) determined mean values for $k^{\prime}$ of $0.00147 \pm 25 \% \mathrm{~d}^{-1}$ $\left(\mu \mathrm{g} \mathrm{C} \mathrm{mL}^{-1}\right)^{-1}$ for mineral soils and $0.00155 \pm$ $65 \% \mathrm{~d}^{-1}\left(\mu \mathrm{g} \mathrm{C} \mathrm{mL}^{-1}\right)^{-1}$ for organic soils.

Actually, good data are still lacking. The experiments by Reddy and others (1984) were performed at high initial nitrate concentration $(200 \mathrm{mg} / \mathrm{L})$ and we need to be careful to insert these $k_{\text {den }}$ values in the equation above. $k_{\text {den }}$ is certainly a good approximation and it is to our knowledge the best that we have. So what is currently missing is a reliable study to establish the rate constants for denitrification and possibly also Michaelis-Menten parameters, both under low and high nitrate concentrations as well as DOC concentration and quality. It may well be that with complex soil organic matter it is the hydrolysis step to generate low molecular weight organic compounds required for denitrification that is rate limiting.

DOC exhibits a wide range of concentrations in various systems. For instance Knorr (2013) determined an average DOC concentration of $25 \mathrm{mg} \mathrm{L}^{-1}$ in a minerotrophic fen in the Fichtelgebirge (Southern Germany), while average DOC values of $2 \mathrm{mg} \mathrm{L}^{-1}$ were determined in the hyporheic zone of a mountain stream in Western Oregon (Zarnetske and others 2011), which is probably at the lower end of DOC values in shallow subsurface environments. Hence, $k^{\prime}$ values may vary between 0.002 and $0.04 \mathrm{~d}^{-1}$ and even higher values at higher DOC concentrations. Therefore, $\tau_{\text {reaction }}(=1 /$ $k^{\prime}$ ) ranges between 25 days (or even shorter) and 500 days. This analysis illustrates that it is mainly the DOC concentration that is driving the reaction time scale rather than the rate constant, given the constant value of $k_{\text {den }}$ cited above.

If we assume DOC concentrations to be rather constant for a certain system (for example, the hyporheic zone discussed above) and also fluctuations of DOC at least under base-flow conditions not to be high (Strohmeier and others 2013), then,
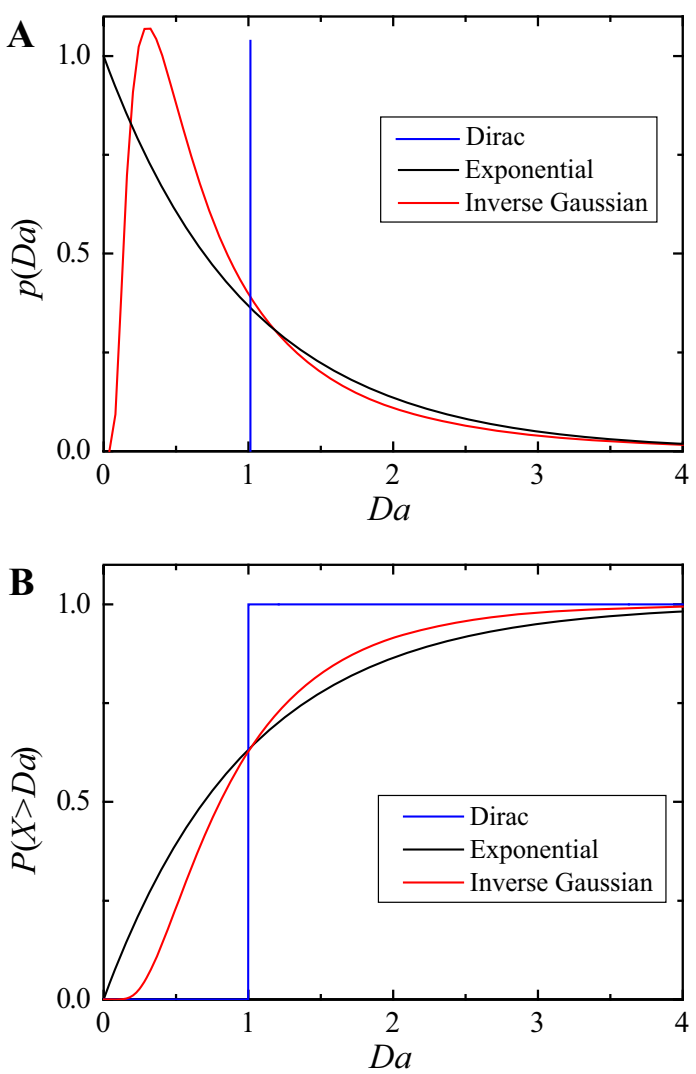

Figure 4. A Illustration of three theoretical Damköhler density distributions $p(D a)$, and $\mathbf{B}$ cumulative distributions $(P(X>D a)$, with the same mean equal to 1 . The Peclet number corresponding to the inverse Gaussian is $P e=0.5$.

$\tau_{\text {reaction }}$ can be assumed to be a roughly constant parameter for that system. Hence, the Damköhler number in this system (and the subsequent nitrate removal capacity) will increase when the transport time, that is, residence time, increases. If we allow for DOC to vary, but can predict this variability as has been successfully done in many environments (for example, Winterdahl and others 2011, 2014); then, there will be more to the temporal dimension than just the change in flow rates.

The broad variability of the nitrate removal capacity also comes from the large variability of the hydrologic and geologic conditions. The RTD in the different hydrologic compartments (unsaturated zone, aquifer, hyporheic, and riparian zones) are not well-peaked Dirac-like distributions but broader distributions that span over large time ranges (Figure 4). Flow heterogeneities from the pore scale to the watershed scale enhance dispersive and mixing processes as larger scales are considered. Additional local-scale trapping, diverting mechanisms in slow diffusive zones, chemical 
sorption, and exchanges between advective and diffusive zones critically enhance the solute spreading in all the spatial directions and the variability of the travel times (Berkowitz and others 2000; Carrera and others 1998; Haggerty and Gorelick 1995).

Such local-scale transport processes may be the key in effective nitrate removal capacities as advection dominated zones may coexist with diffusion dominated zones, differing critically in their residence times and potentially also in their chemical conditions (more anoxic conditions in the diffusive highly denitrifying zones than in the main advection paths). Practically, these mechanisms decouple flow from exposure times in anoxic zones. Both flows and exposure times may remain simultaneously high, while in more advective conditions they are inversely correlated. Nitrate delivery may remain high and nitrate can have long exposure times because of the abovementioned local diffusion processes. Initial synthetic tests indeed indicate that the hydrogeological complexity conditions effective denitrification rates (Green and others 2010, 2014).

Even if multiple scales, multiple domains, and multiple processes intervene in nitrate degradation, the exposure time in anoxic zones distribution remains a good integrative indicator of the transportinduced constraints on reactivity (de Dreuzy and others 2013). For kinetically controlled reactivity, it can be even more straightforwardly compared to the characteristic reaction time, or even to some distributed reaction times if needed, by simple convolution (Böhlke 2002). The ratio of the exposure time to the reaction time (Damköhler number) becomes also broadly distributed and can be further considered to estimate potential denitrification. When assuming a unique denitrification rate, the probability density function of the Damköhler number directly follows from the probability density function of the RTD described by the Dirac, exponential, and inverse Gaussian distributions given in Table 1 and illustrated in Figure 4A for the same mean Damköhler value of 1. It should be noted that the shape of the distribution may have a determinant effect on the denitrification capacity as expressed by the cumulative distribution of the Damköhler number (Figure 4B) even for distributions having been calibrated on the same data (Green and others 2014). This approach requires the a priori choice of a RTD shape but it does not require large amounts of data. Residence time distributions can be calibrated based on data, or derived from flow models and further used in a predictive manner.
Although limited so far (Eberts and others 2012; Green and others 2014), modeling studies show that beyond some consistent choice of the distribution, the most limiting factor is the availability and the accuracy of tracer data. These modeling studies are important as the RTD is never directly accessible from field data but always inferred with some assumptions. Numerical simulations on realistic aquifer structures offer a sound alternative to test beforehand the sensitivity of denitrification to different geological structures and hydrological conditions.

\section{Priority Research Questions}

We have already underlined that up scaling from local assessments from each individual landscape feature is dubious because of the high local spatiotemporal variability of denitrification. But how can plot-scale measurements of the hydrologic processes that link hillslopes, riparian areas, and streams be scaled up to entire catchments? How can we transfer small catchment scale understanding to larger portions of the landscape or other catchments? How can we quantify the effects of different spatial patterns (for example, the distribution of riparian wetlands) within catchments? These questions highlight our current inability to transfer understanding of hydrological processes studied at the plot or hillslope and reach scale to small catchments (Figure 5). These questions beg integrated, multi-scale approaches that combine "landscape level" topographic analysis, processbased field investigations, and catchment-scale integration to identify the factors controlling hydrologic connectivity between source areas with different hydrochemical properties and the flow paths that link source areas to streams. The approach consists of a combination of hydrological landscape analysis to derive the RTD and an assessment of the reaction time scales in different landscape elements (for example, Jencso and others 2010). To these ends several tools are required.

In small drainage basins, that is, less than $10 \mathrm{~km}^{2}$, at any given point in time, the relationship between nitrogen fluxes at the outlet of the catchment and the percentage of land-use, a nonspatially explicit variable, does not hold any more (Burt and Pinay 2005; Strayer and others 2003). We hypothesize that large spatial variability of nutrient fluxes in small drainage basins (Bishop and others 2008) reveal the subtle changes in land cover and land uses as well as the importance of their spatial arrangements. Moreover this absence of relationship between nitrogen fluxes and the 


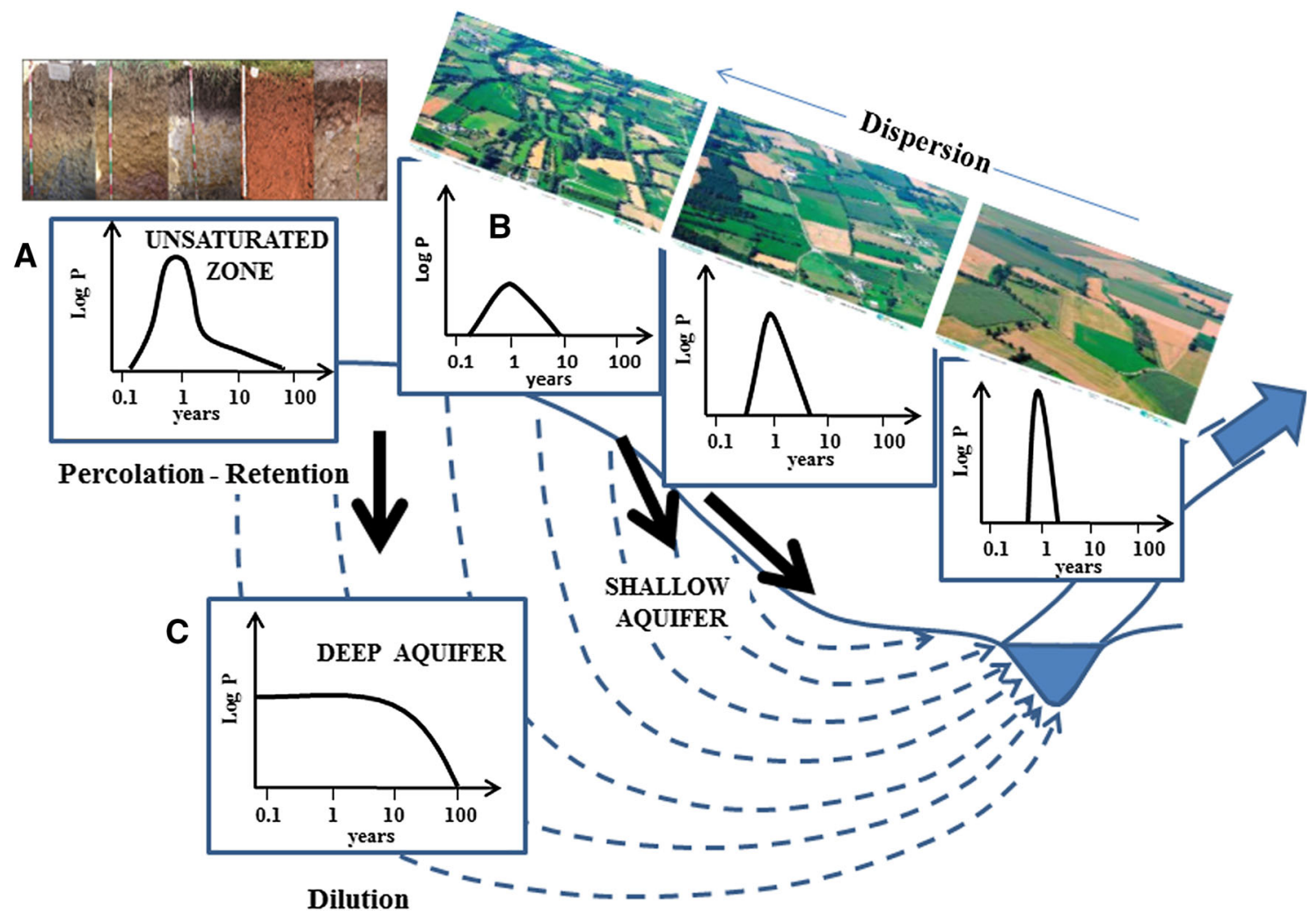

Figure 5. Schematic view of the small drainage basin and hypothetical log-log distribution $(P)$ of nitrate time residence (years) in $\mathbf{A}$ the insaturated zone where percolation/retention patterns occur with a long tail distribution corresponding to biological retention and poorly hydrologically-connected porosity; $\mathbf{B}$ the shallow aquifer with dispersion being a function of the complexity of the landscape structure; and $\mathbf{C}$ in the deep aquifer where dilution occurs.

percentage of land-use reveals also how denitrification efficiency of the spatial architecture changes over time, both in the short term with runoff rates, and seasonally with biological activity, as well as in response to antecedent conditions. Indeed, it is not the total percentage of a given land cover which matters at these small scales but the local arrangement and connectivity of the different land covers and their interfaces, including riparian zones, within the landscape matrix at a given point in time. Therefore, this approach needs to be undertaken in small drainage basins, that is, stream order $\leq 3$ which roughly corresponds to catchments between 1 and $10 \mathrm{~km}^{2}$. This is an important issue because this approach proposes as an underlying statement that landscape structure and land cover arrangement are the key parameters to evaluate the overall nitrate removal capacity at the drainage basin level (Laudon and others 2011).

Although detailed models coupling locally accurate physical and chemical processes can be set up on intensively studied local sites, such models are usually not tractable at small stream order drainage basin scales. We therefore propose an alternative approach that is based on lower data input but a higher degree of generalization and transdisciplinary synthesis from well-studied sites. Nitrate removal capacity is not expected to be highly dynamic; therefore, it will be amenable to estimation based on key proxies that determine the distribution of exposure time in anoxic zones and identify relevant nitrate removal drivers such as the ratio of unsaturated to saturated zones, the extension of the riparian zones, the average rate of quick runoff to slower infiltration and transfer in aquifers, the mixing capacity and chemical inventory (for example, pyrite and organic matter content) of the aquifers, and biological descriptors of nitrate removal efficiency. All these proxies should be identifiable from widely available field data and insights gained from detailed process studies. Such a proxy-based assessment of nitrate removal capacity is consistent with the increasing availability of spatially and temporally resolved data on relevant topographical, hydrological, and geochemical data. We argue that this approach of embedding the expertise and insight gained from more in-depth analysis of a broad diversity of sites 
should be more informative than purely correlative and data-mining analyses. Inter-comparison, benchmarking and in-depth studies conducted on a wide variety of sites are pre-requisites for this approach. For an improved synthesis it will also be advantageous to fully capitalize on the growing mathematical and numerical capacities for scenario simulations and modeling experiments.

Several proxies and tracers of processes that can be used to calibrate, validate, and develop this new approach are presented below. We believe that their use, in combination with hydrological landscape analysis as a means of predicting the denitrification rate at different flow rates through the biogeochemical environments that comprise the catchment, will allow improved models of how water flows through the landscape to continuously change the activity and connectivity of denitrification hotspots (Figure 5).

\section{Tools and Methods Available}

\section{Remote Sensing and Embarked Imagery to Evaluate Landscape Features}

At the landscape scale, a wide range of remote sensing data can be used to reveal the local arrangement of the different land covers and their interfaces, including riparian zones, within the landscape matrix (Rogan and Chen 2004; Goetz 2006). Indeed, satellite and aerial imagery can contribute to determine sites that are suitable for denitrification in given landscape arrangements in the drainage basins. The scale of perception of the drainage network influences the flowpaths and land/water interface length (Gold and others 2001), especially when analyzing them through data provided by remotely sensed imagery. Instruments such as airborne lasers light detection and ranging (LiDAR) provide innovative contributions to the detection and mapping of the drainage network as well as the wet/dry interface length at a fine scale. LiDAR data have been used to characterize the ground microtopography with centimeter accuracy, including ditches and streams, even under tree cover (James and others 2007) or herbaceous vegetation (Hopkinson and others 2005).

The accuracy of Digital Terrain Models (DTMs) generated with LiDAR data, which are most often constructed in a given spatial resolution according to the size of the study area, depends on the LIDAR point density. The drainage network can be automatically detected using form criteria derived from LiDAR data, either indirectly from the DTM (Pirotti and Tarolli 2010) or directly from the point cloud
(Bailly and others 2008). Most studies conducted on the mapping of the drainage network with such data are focused on the identification of network elements, including small ditches and the historical drainage network (Werbrouck and others 2011) without characterizing them. However, information such as the width or depth of streams and ditches that are needed for biogeochemical functions like denitrification can also be determined with a high level of precision (Rapinel and others 2013). Bathymetry of the drainage network can be reconstructed from the slopes of the emerged banks, but this type of model requires many land surveys (Merwade and others 2008). Hence, the wet/dry interface length can be accurately mapped from DTMs generated from LiDAR data and integrated in models based on topographic indices to evaluate the surface of potentially wetted areas within a drainage basin. The spatio-temporal quantification of this proxy can be achieved using other active imaging sensors. Observations in nearsurface aquifers may however be limited. Simple models should then be used to propose assumptions for their structure. It is especially the case for the weathered zone of crystalline basements. The free-surface aquifer is controlled by chemical weathering reactions and by percolation processes. For example, in the case of non-limiting chemical weathering, Rempe and Dietrich (2014) propose a "bottom-up" model of the weathered profile, which can be considered as a proxy of small drainage basin shallow aquifers. At equilibrium between erosion and uplift, the weathered zone is bounded above by the sediment export capacity from the hillslope to the river and below by the persistent saturation of the slowly drained fresh bedrock.

\section{Process-Based Models of Hydrologically Mediated Turnover}

Small-scale process-based flow and transport models are now a common tool to evaluate hydrologic dynamics and biogeochemical turnover at compartment interfaces in the landscape. Especially for the groundwater-surface water interface such models have been widely used to quantify groundwater-surface water exchange dynamics (for example, Frei and others 2012) and hyporheic flows in 2D (for example, Cardenas and Wilson 2007a, b) and 3D (for example, Tonina and Buffington 2007; Trauth and others 2013) as well as associated biogeochemical turnover (for example, Bardini and others 2012; Trauth and others 2014). These models are typically used as learning tools to 
derive a general mechanistic understanding of hydrologic dynamics and the resulting biogeochemical process patterns. For example, they can elucidate the dominant hydrologic controls for the development of biogeochemical hotspots in the riparian zone (Frei and others 2012) or biogeochemical zonations in meander bends (Boano and others 2010; Gomez and others 2012) and in the hyporheic zone (Marzadri and others 2011, 2012; Bardini and others 2012; Trauth and others 2014). Model results can replicate observed patterns and link them to the controlling processes and mechanisms. A more integral assessment of biogeochemical turnover may be achievable based on RTDs, which can be obtained from the hydrologic models (for example, Cardenas and others 2008). In a field study of an instream gravel bar (Zarnetske and others (2011), 2012a, b) demonstrated that nitrogen turnover in the hyporheic zone was clearly correlated with median residence time of the hyporheic water and that denitrification capacity of the gravel bar could be described in terms of Damköhler numbers. There is some evidence that such relationships may also hold for small catchments as long as they are structurally not too complex (van der Velde and others 2010, 2012) and predictable (Bishop and others 2011; Winterdahl and others 2014). A further complication is the transient nature of catchment-scale RTDs. However, van der Velde and others (2012) could show that for differently structured hill slopes, and presumably also for small catchments, transient RTDs can be collapsed into a unique, time invariant probability distribution function for the outflow of water of a specific age. If this function can be parameterized based on readily obtainable catchment characteristics, a process-based, integral description of catchment-scale denitrification might be possible without the need for a complex process-based model.

However, due to the inherent complexities of natural systems, especially at larger scales, and the nested scales involved, it is still challenging to adequately infuse results from these models into descriptions of matter fluxes and turnover at larger scales such as entire catchments (for example, in models like SWAT). Other, more conceptual modeling frameworks that link local processes to integral catchment response may emerge from the combination of enhanced local process understanding and improved integral descriptions of denitrification (for example, via proxies and refined landscape analysis) and may provide viable alternatives to currently existing models. To further develop, test, and refine such a new modeling framework we need adequate tracers and methods to describe the relevant key processes. The following sections provide examples of these tracers and methods.

\section{Atmospheric Gases for Assessing Aquifer Residence Times}

Atmospheric gases of anthropogenic origin including chlorofluorocarbons (CFC-11, CFC-12, CFC113), sulfur hexafluoride (SF6), and Krypton-85 provide excellent tools for RTD in aquifers. Their atmospheric concentrations are well known and relatively uniform. Once in the saturated zone and without any exchange with the atmosphere, they provide excellent tracers of the aquifer circulations (Cook and Solomon 1995; Cook and others 1995; Newman and others 2010; Reilly and others 1994). They give essential information on the aquifer residence times from a few years up to around 50 years. Concentration measurements and interpretation require however some expertise. Because of low concentration levels, samples should avoid any contact with the atmosphere at any time of the sampling and analysis (Ayraud and others 2008). For SF6, geogenic production may occur in crystalline rocks and may reduce its applicability (Busenberg and Plummer 2000). Derivation of the RTD from the measured concentration also requires some a priori assumptions on the site-relevant dispersion of the residence times (Eberts and others 2012; Leray and others 2012; Massoudieh and Ginn 2011; Massoudieh and others 2012; Waugh and others 2003).

\section{Heat as a Tracer to Elucidate Groundwater/Surface Exchange Processes}

Using heat as a tracer has become a popular tool to characterize and quantify groundwater-surface water exchange processes (Constantz 2008). Natural temperature differences between ground and surface water can be used to qualitatively map exchange patterns (for example, Conant 2004), or to quantitatively invert flux rates based on numerical (for example, Constantz and others 2013) or simpler analytical solutions to the heat transport equation (for example, Hatch and others 2006; Schmidt and others 2006). Several analytical methods based on either an analysis of the amplitude damping and phase shift of transient temperature signals (Hatch and others 2006; Keery and others 2007) or a quasi-steady state evaluation of vertical temperature profiles (Schmidt and others $2006,2007)$ have been proposed to quantify ex- 


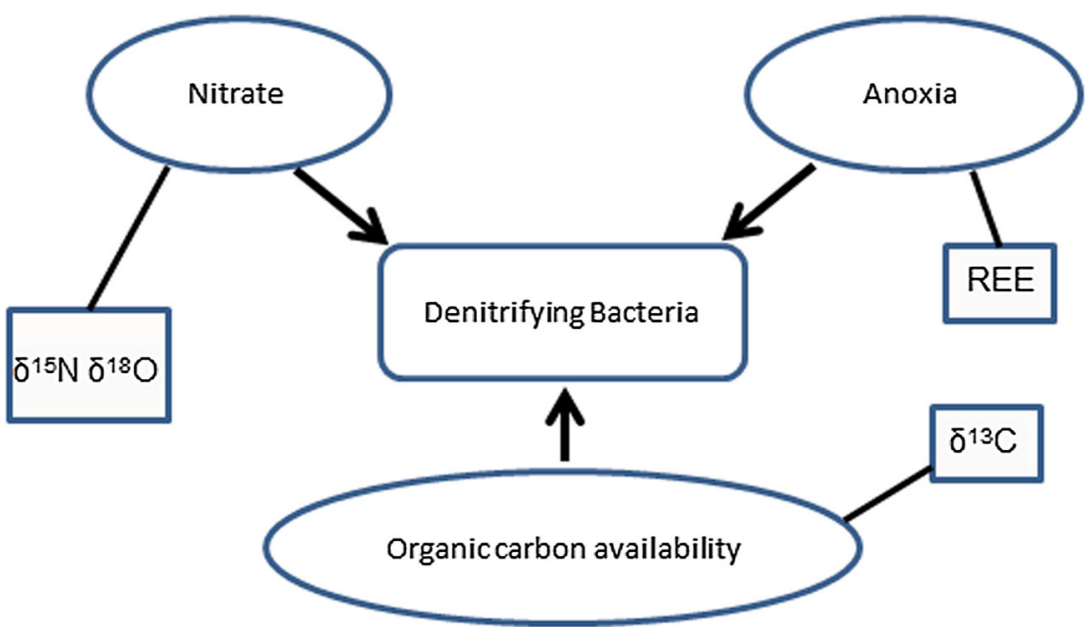

Figure 6. Geochemical proxies of the denitrification proximal drivers.

change fluxes. Despite their inherent simplifying assumptions these methods can provide reliable flux estimates over quite a broad range of field conditions (Anibas and others 2009; Lautz 2010; Munz and others 2011; Schornberg and others 2010) and allow a relatively simple means to characterize and quantify spatial exchange patterns (Anibas and others 2011). In addition easy-to-use software tools to estimate exchange fluxes based on these methods have become available (Swanson and Cardenas 2011; Gordon and others 2012). Spatially explicit flux estimates can in turn be linked to patterns of nitrogen turnover to identify and explain biogeochemical hotspots at the surface water-groundwater interface (Krause and others 2009, 2013; Briggs and others 2013). For even smaller-scale $(<1 \mathrm{~m})$ assessments of fluxes in streambeds active heat-pulse methods have been developed (Lewandowski and others 2011; Angermann and others 2012a), which allow quantification of small-scale spatial patterns of hyporheic exchange, which are superimposed onto the largerscale river-aquifer exchange patterns (Bhaskar and others 2012; Angermann and others 2012b). At larger stream reach scale, substantial progress in identifying spatial patterns of groundwater-surface water exchange fluxes has been made by applying distributed fiber-optic temperature sensors (FODTS, Selker and others 2006). FO-DTS analyzes the backscatter of a laser signal propagating through a fiber-optic cable of up to several kilometers length, in this case ideally installed in the streambed or at the streambed-surface water interface. Using the seasonally variable difference in groundwater and surface water temperatures, groundwater upwelling is identified by hot or cold anomalies as long as end-member temperatures are significantly different. Although FO-DTS has been applied suc- cessfully for delineating groundwater-surface water exchange fluxes at multiple scales, its capabilities to provide quantitative predictions of fluxes remain limited and accuracies strongly depend on the existence of a suitable signal strength and signal size as well as correct calibration procedures (Rose and others 2013).

\section{Isotopic Methods to Trace Sources of N and Denitrification}

One of the major challenges of current research on the functioning of the continental environment is to develop integrative approaches allowing scale changes. Isotopic biogeochemistry is an important integrating tool. The basic idea is that the isotopic composition of a chemical species $\left(\delta^{15} \mathrm{~N}\right.$ for nitrogen) at a definite location reflects (i) its various sources and (ii) processes that affect its concentration (Figure 6). Despite some interpretation difficulties, especially in case of sewage treatment plants or manure application (Bedard-Haughn and others 2003), this method allows detection of the importance of denitrification activity in landscapes. $\delta^{15} \mathrm{~N}$ signatures of plants and organisms are increasingly being used to identify the sources of $\mathrm{N}$ in aquatic environments, and to identify sites where extensive $\mathrm{N}$ cycling or transformations are occurring (Udy and Bunn 2001). It assumes that the $\delta^{15} \mathrm{~N}$ of the riparian or aquatic vegetation will reflect its source, that is, the in-stream dissolved organic $\mathrm{N}$ or the groundwater. This may have been fractionated due to biogeochemical processes in transit. The $\mathrm{N}$ may also undergo small fractionation during assimilation within the plant (Udy and Bunn 2001) although Mariotti and others (1982) and Fry (1991) suggest that nitrate uptake by terrestrial vegetation appears to fractionate minimally or not 
at all (Clément and others 2003). Moreover, it was shown that diffusion and advection (physical processes) do not affect the isotopic composition of nitrate (Mariotti and others 1982; Semaoune and others 2012). Thus, any change in $\delta^{15} \mathrm{~N}$ along flow paths can result either from a mixing of two different water bodies or from nitrification and/or denitrification. Moreover, a concomitant increase of $\delta^{15} \mathrm{~N}$ and $\delta^{18} \mathrm{O}$ in the nitrate confirms the role of denitrification compared to mixing origin (Kendall1998; Sébilo and others 2006). When process rates are limited by nitrate diffusion through the water-sediment interface, the isotopic fractionation associated with denitrification is very poor. For this reason, only riparian denitrification (vs. benthic or in stream denitrification) generates a significant isotopic anomaly which leads an increase of the heavier fraction in the isotopic composition of nitrate $\left({ }^{15} \mathrm{~N}\right.$ and $\left.{ }^{18} \mathrm{O}\right)$ with the decrease of nitrate concentration (Sébilo and others 2003).

\section{Identify Anoxic Sites by Carbon Isotope Measurements of Dissolved Organic Carbon}

The ${ }^{13} \mathrm{C} /{ }^{12} \mathrm{C}$ ratio of DOC could be used as a guide to quantify the proportion of DOM (and of waters) coming from wetlands, potential denitrification hotspots (Figure 6). Indeed, distinctively different carbon isotope signature can be expected for the DOM coming from uplands and adjacent wetlands because in the oxidative environment of the uplands, oxidative processes dominate during the decomposition of plant materials. Due to isotopic fractionation during those processes, residues are increasingly enriched in the heavier carbon isotopes $\left({ }^{13} \mathrm{C}\right)$ as the lighter ${ }^{12} \mathrm{C}$ will be preferentially involved in chemical reactions (for example, Wynn and others 2006). In contrast, wetland soils are characterized by anoxic conditions. The lack of oxygen results in an incomplete decomposition of organic material by anaerobic bacteria. Carbon compounds are preserved to a higher degree and keep their original (plant) isotopic signature. Therefore, the $\delta^{13} \mathrm{C}$ of soil organic matter in wetland soils is anticipated to be lighter than those of upland soils (Schaub and Alewell 2009). Thus, the $\delta^{13} \mathrm{C}$ of DOM in stream and river water provides a potentially extremely powerful tool to quantify the overall degree of interaction of drainage waters with wetland domains.

Another important distinction with the landscape can be between extended wetlands with a larger proportion of direct precipitation inputs compared to groundwater interactions, and fens where there is a greater proportion of groundwater. The differences between precipitation and groundwater chemistry have created different biogeochemical environments, and different chemical inputs to the suboxic to anoxic organogenic matrices bordering the surface water network. These differences lead to differences in the absorbance properties of the runoff water which can be used to determine the ratio of extended wetlands to forested fens (Berggren and others 2007; Laudon and others 2011). Given the complex nature of organic carbon, there are other potential tracers of C source environment that can be marshaled to the purpose of delineating dynamic contributions from different catchment environments. The basic starting point for this work with carbon character tracers is to measure the soil organic matter and DOM along upslope-riparian zone transects. These measurements, together with analysis of the DOM isotopic composition along water flow paths, can be used to quantify interaction of surface and subsurface water flows with denitrification hotspots. Although in-stream processing of carbon can eventually alter these carbon tracers, the focus of the new framework on headwater networks means that the time available for such processes is measured in hours to a day or two, limiting the scope for these processes to obscure the signal from these tracers of catchment DOM origin.

\section{Rare Earth Elements}

Marked negative Cerium (Ce) anomalies in groundwater are due to oxidation of $\mathrm{Ce}^{3+}$ to $\mathrm{Ce}^{4+}$ and subsequent secondary precipitation of cerianite (Figure 6). However, the Ce behavior in organicrich waters is not completely controlled by redox processes. Indeed, the surface properties of dissolved organic matter are able to complex the Lanthanide series (rare earth elements: REE), including $\mathrm{Ce}$, which has been shown to inhibit the development of negative Ce anomaly in waters (Dia and others 2000; Gruau and others 2004; Davranche and others 2005; Pourret and others 2010). Therefore, the extent of negative Ce anomaly development in ground and stream water can be used to quantify the degree of interaction of these waters with organic-rich zones in the basins, that is, with those areas where the electron acceptors necessary for the denitrification process to develop predominantly occur. More specifically, stream water showing no or insignificant negative Ce anomalies will be indicative of drainage basins where the ratio between potential denitrification landscape units (that is, wetland zones, thick 
organic-rich soil horizons,...) and overall water flux is high (high denitrification potential), while stream showing the reverse situation (that is, deep negative Ce anomalies) will be indicative of the opposite, that is, of basins where the ratio between potential denitrification units and effective water flux is low.

\section{ConClusion}

Small catchments constitute more than $80 \%$ of the drainage area of large river basins; thus they provide the right spatial scale for effective intervention to achieve water quality goals. Yet, an appropriate framework and methods to quantify the relationship between landscape structure/use and nitrogen fluxes/retention/removal is still lacking. We use an analysis of the existing frameworks related to denitrification as the basis for proposing a step forward in coupling landscape structures to denitrification at the small drainage basin scale. We propose to combine the landscape structure and the dynamic patterns of flow through that landscape pattern arrangement which produce the exposure times in anoxic zones and chemical inputs to denitrifying environments. In this context, exposure time distribution and Damköhler ratios provide an efficient means to evaluate and compare the denitrification capacity of different landscape units. Systematically combining local, processbased, and catchment-scale, integral assessments of denitrification capacity may ultimately lead to new modeling concepts to quantify catchment-scale denitrification. Integration of existing frameworks with new tools and methods offers the potential for significant breakthroughs in the quantification and modeling of denitrification in small drainage basins. This can provide a basis for improved protection and restoration of surface water and groundwater quality. Focusing on the hydrogeochemical architecture of small drainage basins can help place them in the center of monitoring and management issues related to protection and restoration of water quality.

\section{ACKNOWLEDGMENTS}

This paper was supported by the European Union International Training Network "Interfaces: Ecohydrological interfaces as critical hotspots for transformations of ecosystem exchange fluxes and biogeochemical cycling" and the French Programme National Programme EC2CO «Continental and Coastal Ecosphere», as well as the Rennes Métropole installation grant allocated to the lead author. The authors would like to thank four anonymous reviewers for their comments and recommendations which greatly helped improving the manuscript.

\section{OPEN ACCESS}

This article is distributed under the terms of the Creative Commons Attribution 4.0 International License (http://creativecommons.org/licenses/by/ 4.0/), which permits unrestricted use, distribution, and reproduction in any medium, provided you give appropriate credit to the original author(s) and the source, provide a link to the Creative Commons license, and indicate if changes were made.

\section{REFERENCES}

Alexander RB, Smith RA, Schwarz GE. 2000. Effect of stream channel size on the delivery of nitrogen to the Gulf of Mexico. Nature 403:758-61.

Angermann L, Krause S, Lewandowski J. 2012. Application of heat pulse injections for investigating shallow hyporheic flow in a lowland river. Water Resour Res 48: Article Number: W00P02.

Angermann L, Lewandowski J, Fleckenstein JH, Nuetzmann G. 2012b. A 3D analysis algorithm to improve interpretation of heat pulse sensor results for the determination of small-scale flow directions and velocities in the hyporheic zone. J. Hydrol. 475:1-11

Anibas C, Fleckenstein JH, Volze N, Buis K, Verhoeven R, Meire P, Batelaan O. 2009. Transient or steady-state? Using vertical temperature profiles to quantify groundwater-surface water exchange. Hydrol Process 23(15):2165-77.

Anibas C, Buis K, Verhoeven R, Meire P, Batelaan O. 2011. A simple thermal mapping method for seasonal spatial patterns of groundwater-surface water interaction. J Hydrol 397(12):93-104.

Arheimer B, Brandt M. 1998. Modelling nitrogen transport and retention in the catchments of southern Sweden. Ambio 27(6):471-80.

Arnold JG, Srinivasan R, Muttiah RS, Williams JR. 1998. Large area hydrologic modeling and assessment-Part 1: model development. J Am Water Resour Assoc 34(1):73-89.

Ayraud V, Aquilina L, Labasque T, Pauwels H, Molenat J, Pierson-Wickmann AC, Durand V, Bour O, Tarits C, Le Corre P, Fourre E, Merot P, Davy P. 2008. Compartmentalization of physical and chemical properties in hard-rock aquifers deduced from chemical and groundwater age analyses. Appl Geochem 23(9):2686-707.

Bailly JS, Lagacherie P, Millier C, Puech C, Kosuth P. 2008. Agrarian landscapes linear features detection from LiDAR: application to artificial drainage networks. Int J Remote Sens 29(12):3489-508.

Bardini L, Boano F, Cardenas MB, Revelli R, Ridolfi L. 2012. Nutrient cycling in bedform induced hyporheic zones. Geochim Cosmochim Acta 84:47-61.

Bear J. 1973. Dynamics of fluids in porous media. New York: Dover Publications.

Bedard-Haughn A, van Groenigen JW, van Kessel C. 2003. Tracing $15 \mathrm{~N}$ through landscapes: potential uses and precautions. J Hydrol 272:175-90. 
Berggren M, Laudon H, Jansson M. 2007. Landscape regulation of bacterial growth efficiency in boreal freshwaters. Global Biogeochem Cycles 21: doi:10.1029/2006GB002844.

Berkowitz B, Scher H, Silliman S. 2000. Anomalous transport in laboratory-scale, heterogeneous porous media. Water Resour Res 36(1):149-58.

Beven KJ, Kirkby MJ. 1979. A physically based variable contributing area model of basin hydrology. Hydrol Sci Bull 24:43-69.

Bhaskar AS, Harvey JW, Henry EJ. 2012. Resolving hyporheic and groundwater components of streambed water flux using heat as a tracer. Water Resour Res 48: Article Number: W08524.

Bishop K, Buffam I, Erlandsson M, Folster J, Laudon H, Seibert J, Temnerud J. 2008. Aqua Incognita: the unknown headwaters. Hydrol Process 22:1239-42.

Bishop K, Seibert J, Nyberg L, Rodhe A. 2011. Water storage in a till catchment II: implications for flow paths, turnover times and transmissivity feedback. Hydrol Process 25(25):3950-9.

Boano F, Demaria A, Revelli R, Ridolfi L. 2010. Biogeochemical zonation due to intrameander hyporheic flow. Water Resour Res 46: doi:10.1029/2010WR009185.

Bohlke JK. 2002. Groundwater recharge and agricultural contamination. Hydrogeol J 10(1):153-79.

Briggs MA, Lautz LK, Hare DK, Gonzalez-Pinzon R. 2013. Relating hyporheic fluxes, residence times, and redox-sensitive biogeochemical processes upstream of beaver dams. Freshw Sci 32(2):622-41.

Brinson MM, Bradshaw HD, Kane ES. 1984. Nutrient assimilative capacity of an alluvial floodplain swamp. J Appl Ecol 21:1041-57.

Burt TP, Pinay G, Matheson FE, Haycock NE, Butturini A, Clément JC, Danielescu S, Dowrick D, Hefting M, HilbrichtIlkowska A, Maitre V. 2002. Water table fluctuations in riparian zone: comparative results from a pan European experiment. J Hydrol 265:129-48.

Burt TP, Pinay G. 2005. Linking hydrology and biogeochemistry in complex landscapes. Prog Phys Geogr 29(3):297-316.

Burt TP, Pinay G, Sabater S. 2010. What do we still need to know about the ecohydrology of riparian zones? Ecohydrology 3:373-7.

Busenberg E, Plummer LN. 2000. Dating young groundwater with sulfur hexafluoride: natural and anthropogenic sources of sulfur hexafluoride. Water Resour Res 36(10):3011-30.

Cardenas MB, Wilson JL. 2007a. Exchange across a sedimentwater interface with ambient groundwater discharge. J Hydrol 346(3-4):69-80.

Cardenas MB, Wilson JL. 2007b. Hydrodynamics of coupled flow above and below a sediment-water interface with triangular bedforms. Adv Water Resour 30(3):301-13.

Cardenas MB, Wilson JL, Haggerty R. 2008. Residence time of bedform-driven hyporheic exchange. Adv Water Resour 31(10):1382-6.

Carrera J, Sánchez-Vila X, Benet I, Medina A, Galarza G, Guimerà J. 1998. On matrix diffusion: formulations, solution methods and qualitative effects. Hydrogeol J 6(1):178-90.

Clément JC, Holmes RM, Peterson BJ, Pinay G. 2003. Isotopic investigation of denitrification in a riparian ecosystem in western France. J Appl Ecol 40:1035-48.

Conant B. 2004. Delineating and quantifying ground water discharge zones using streambed temperatures. Ground Water $42(2): 243-57$.
Constantz J. 2008. Heat as a tracer to determine streambed water exchanges. Water Resour Res 44: Article Number W00D10.

Constantz J, Eddy-Miller CA, Wheeler JD, Essaid HI. 2013. Streambed exchanges along tributary streams in humid watersheds. Water Resou Res 49(4):2197-204.

Cook P, Solomon DK. 1995. Transport of atmospheric trace gases to the water table. Implication for groundwater dating with chlorofluorocarbons and krypton-85. Water Resour Res 31(2):263-70.

Cook PG, Solomon DK, Plummer LN, Busenberg E, Schiff SL. 1995. Chlorofluorocarbons as tracers of groundwater transport processes in a shallow, silty sand aquifer. Water Resour Res 31(3):425-34.

Davranche M, Pourret O, Gruau G, Dia A, Le Coz-Bouhnik M. 2005. Adsorption of REE(III)-humate complexes onto $\mathrm{MnO}_{2}$ : experimental evidence for cerium anomaly and lanthanide tetrad effect suppression. Geochem Cosochim Acta 69(20):4825-35.

de Dreuzy JR, Rapaport A, Babey T, Harmand J. 2013. Influence of porosity structures on mixing-induced reactivity at chemical equilibrium in mobile/immobile Multi-Rate Mass Transfer (MRMT) and Multiple INteracting Continua (MINC) models. Water Resour Res 49(12):8511-30.

Décamps H, Pinay G, Naiman RJ, Petts GE, McClain ME, Hilbricht-Ilkowska A, Hanley TA, Holmes RM, Quinn J, Gibert J, Planty-Tabacchi AM, Schiemer F, Tabacchi E, Zalewski M 2004. Riparian zones: where biogeochemistry meets biodiversity in management practice. Polish J Ecol 52(1):3-18.

Dia A, Gruau G, Olivie-Lauquet G, Riou C, Molenat J, Curmi P. 2000. The distribution of rare earth elements in groundwaters: assessing the role of source-rock composition, redox changes and colloidal particles. Geochem et Cosochim Acta 64(24):4131-51.

Diaz RJ, Rosenberg R. 2008. Spreading dead zones and consequences for marine ecosystems. Science 321(5891):926-9.

Duncan JM, Groffman PM, Band LE. 2013. Towards closing the watershed nitrogen budget: spatial and temporal scaling of denitrification. J Geophys Res Biogeosci 118(3):1105-19.

Duval PT, Hill AR. 2006. Influence of stream bank seepage during low-flow conditions on riparian zone hydrology. Water Resour Res 42(10): Article Number W10425.

Eberts SM, Bohlke JK, Kauffman LJ, Jurgens BC. 2012. Comparison of particle-tracking and lumped-parameter age-distribution models for evaluating vulnerability of production wells to contamination. Hydrogeol J 20(2):263-82.

EU 2000. Framework for Community action in the field of water policy. European Union Directive 2000/60/EC. 72 p.

Ficklin DL, Luo YZ, Zhang MH. 2013. Watershed modelling of hydrology and water quality in the Sacramento River watershed, California. Hydrol Process 27(2):236-50.

Frei S, Knorr KH, Peiffer S, Fleckenstein JH. 2012. Surface micro-topography causes hot spots of biogeochemical activity in wetland systems: a virtual modeling experiment. J Geophys Res Biogeosci 117 doi:10.1029/2012JG002012

Fry B. 1991. Stable isotope diagrams of freshwater foodwebs. Ecology 72:2293-7.

Galloway JN, Townsend AR, Erisman JW, Bekunda M, Cai Z, Freney JR, Martinelli LA, Seitzinger SP, Sutton MA. 2008. Transformation of the nitrogen cycle: recent trends, questions, and potential solutions. Science 320:889-92.

Gelhar LW, Welti C, Rehfeld KR. 1992. A critical review of data on field-scale dispersion in aquifers. Water Resour Res 28(7):1955-74. 
Goetz SJ. 2006. Remote sensing of riparian buffers: past progress and future prospects. J Am Water Resour Assoc 42:133-43.

Gold AJ, Groffman PM, Addy K, Kellogg DQ, Stolt M, Rosenblatt AE. 2001. Landscape attributes as controls on ground water nitrate removal capacity of riparian zones. J Am Water Resour Assoc 37(6):1457-64.

Gomez JD, Wilson JL, Cardenas MB. 2012. Residence time distributions in sinuosity-driven hyporheic zones and their biogeochemical effects. Water Resour Res 48: doi:10.1029/ 2012WR012180.

Gordon RP, Lautz LK, Briggs MA, McKenzie JM. 2012. Automated calculation of vertical pore-water flux from field temperature time series using the VFLUX method and computer program. J Hydrol 420:142-58.

Grabs T, Bishop K, Laudon H, Lyon SW, Seibert J. 2012. Riparian zone hydrology and soil water total organic carbon (TOC): implications for spatial variability and upscaling of lateral riparian TOC exports. Biogeosciences 9:3901-16.

Green CT, Boehlke JK, Bekins BA, Phillips SP. 2010. Mixing effects on apparent reaction rates and isotope fractionation during denitrification in a heterogeneous aquifer. Water Resour Res 46: W08525 DOI: 10.1029/2009WR008903.

Green CT, Zhang Y, Jurgens BC, Starn JJ, Landon MK. 2014. Accuracy of travel time distribution (TTD) models as affected by TTD complexity, observation errors, and model and tracer selection. Water Resour Res 50:6191-213.

Groffman PM, Altabet MA, Bohlke JK, Butterbach-Bahl K, David MB, Firestone MK, Giblin AE, Kana TM, Nielsen LP, Voytek MA. 2006. Methods for measuring denitrification: diverse approaches to a difficult problem. Ecol Appl 16(6):2091-122.

Gruau G, Dia A, Olivié-Lauque G, Davranche M, Pinay G. 2004. Controls on the distribution of rare earth elements in shallow groundwater. Water Res 38:3576-86.

Gu C, Hornberger GM, Mills AL, Herman JS, Flewelling SA. 2007. Nitrate reduction in streambed sediments: effects of flow and biogeochemical kinetics. Water Resour Res 43: W12413, doi:10.1029/2007WR006027

Gurwick NP, McCorkle DM, Groffman PM, Gold AJ, Kellogg DQ, Seitz-Rundlett P. 2008. Mineralization of ancient carbon in the subsurface of riparian forests. J Geophys Res Biogeosci 113: doi:10.1029/2007JG000482.

Haggerty R, Gorelick SM. 1995. Multiple-rate mass transfer for modeling diffusion and surface reactions in media with porescale heterogeneity. Water Resour Res 31(10):2383-400.

Hatch CE, Fisher AT, Revenaugh JS, Constantz J, Ruehl C. 2006. Quantifying surface water-groundwater interactions using time series analysis of streambed thermal records: Method development. Water Resour Res 42(10): doi:10.1029/ 2005 WR004787.

Hattermann FF, Krysanova V, Habeck A, Bronstert A. 2006. Integrating wetlands and riparian zones in river basin modelling. Ecol Modell 199(4):379-92.

Hill AR, Labadia CF, Sanmugadas K. 1998. Hyporheic zone hydrology and nitrogen dynamics in relation to the streambed topography of a N-rich stream. Biogeochemistry 42(3):285-310.

Hopkinson C, Chasmer LE, Sass G, Creed IF, Sitar M, Kalbfleisch W, Treitz P. 2005. Vegetation class dependent errors in lidar ground elevation and canopy height estimates in a boreal wetland environment. Can J Remote Sens 31(2):191-206.

James LA, Watson DG, Hansen WF. 2007. Using LiDAR data to map gullies and headwater streams under forest canopy: South Carolina, USA. Catena 71(1):132-44.
Jencso KG, McGlynn BL, Gooseff MN, Bencala KE, Wondzell SM. 2010. Hillslope hydrologic connectivity controls riparian groundwater turnover: implications of catchment structure for riparian buffering and stream water sources. Water Resour Res 46(10): Article Number W10524.

Keery J, Binley A, Crook N, Smith JWN. 2007. Temporal and spatial variability of groundwater-surface water fluxes: development and application of an analytical method using temperature time series. J Hydrol 336(1-2):1-16.

Kendall C. 1998. Tracing nitrogen sources and cycling in catchments. In: Kendall C, McDonnell JJ, Eds. Isotope tracers in catchment hydrology. Amsterdam: Elsevier. p 519-76.

Knorr KH. 2013. DOC dynamics in a small headwater catchment as driven by redox fluctuations and hydrological flow paths-are DOC exports mediated by iron reduction/oxidation cycles? Biogeosciences 10:891-904.

Krause S, Heathwaite AL, Binley A, Keenan P. 2009. Nitrate concentration changes along the groundwater-surface water interface of a small Cumbrian river. Hydrol Process 23(15):2195-211.

Krause S, Tecklenburg C, Munz M, Naden E. 2013. Streambed nitrogen cycling beyond the hyporheic zone: flow controls on horizontal patterns and depth distribution of nitrate and dissolved oxygen in the upwelling groundwater of a lowland river. J Geophys Res Biogeosci 118(1):54-67.

Krysanova V, Muller-Wohlfeil DI, Becker A. 1998. Development and test of a spatially distributed hydrological water quality model for mesoscale watersheds. Ecol Modell 106(2-3):261-89.

Lam QD, Schmalz B, Fohrer N. 2010. Modelling point and diffuse source pollution of nitrate in a rural lowland catchment using the SWAT model. Agric Water Manag 97(2):317-25.

Laudon H, Berggren M, Agren A, Buffam I, Bishop K, Grabs T, Jansson M, Kohler S. 2011. Patterns and dynamics of dissolved organic carbon (DOC) in Boreal streams: the role of processes, connectivity, and scaling. Ecosystems 14(6):88093.

Lautz LK. 2010. Impacts of nonideal field conditions on vertical water velocity estimates from streambed temperature time series. Water Resour Research 46: Article Number: W01509.

Leray S, de Dreuzy JR, Bour O, Labasque T, Aquilina L. 2012. Contribution of age data to the characterization of complex aquifers. J Hydrol 464:54-68.

Lewandowski J, Angermann L, Nuetzmann G, Fleckenstein JH. 2011. A heat pulse technique for the determination of smallscale flow directions and flow velocities in the streambed of sand-bed streams. Hydrol Process 25(20):3244-55.

Mariotti A, Germon JC, Leclerc A, Catroux G, Letoile R. 1982. Experimental determination of kinetic isotope fractionation of nitrogen isotopes during denitrification. In: Schmidt HL, Forstel H, Keinoingen H, Eds. Stable isotopes. Amsterdam: Elsevier. p 459-64.

Marzadri A, Tonina D, Bellin A. 2011. A semianalytical threedimensional process-based model for hyporheic nitrogen dynamics in gravel bed rivers. Water Resources Research 47: Article number W11518.

Marzadri A, Tonina D, Bellin A. 2012. Morphodynamic controls on redox conditions and on nitrogen dynamics within the hyporheic zone: application to gravel bed rivers with alternate-bar morphology. J Geophys Res Biogeosci 117: Article number G00N10.

Massoudieh A, Ginn TR. 2011. The theoretical relation between unstable solutes and groundwater age. Water Resour Res 47: Article Number: W10523. 
Massoudieh A, Sharifi S, Solomon DK. 2012. Bayesian evaluation of groundwater age distribution using radioactive tracers and anthropogenic chemicals. Water Resour Res 48: Article number 09529

McClain ME, Boyer EW, Dent CL, Gergel SE, Grimm NB, Groffman PM, Hart SC, Harvey JW, Johnston CA, Mayorga E, McDowell WH, Pinay G. 2003. Biogeochemical hot spots and hot moments at the interface of terrestrial and aquatic ecosystems. Ecosystems 6:301-12.

McGlynn BL, McDonnell JJ, Shanley JB, Kendall C. 1999. Riparian zone flowpath dynamics during snowmelt in a small headwater catchment. J Hydrol 222:75-92.

McGlynn BL, McDonnell JJ. 2003. Quantifying the relative contributions of riparian and hillslope zones to catchment runoff and composition. Water Resour Res 39(11): Article Number 1310.

McGlynn BL, Seibert J. 2003. Distributed assessment of contributing area and riparian buffering along stream networks. Water Resour Res 39(4): doi:10.1029/2002WR001521.

McGlynn BL, McDonnell JJ, Seibert J, Kendall C. 2004. Scale effects on headwater catchment runoff, flow sources, and groundwater-streamflow relations. Water Resour Res Article Number W07504

McGuire KJ, McDonnell JJ, Weiler M, Kendall C, McGlynn BL, Welker JM, Seibert J. 2005. The role of topography on catchment-scale water residence time. Water Resour Res 41(5): Article Number W05002.

Mérot P, Squividant H, Aurousseau P, Hefting M, Burt T, Maitre V, Kruk M, Butturini A, Thenail C, Viaud V. 2003. Testing a climatotopographic index for predicting wetlands distribution along an European climate gradient. Ecol Modell 163(1-2):51-71.

Merwade V, Cook A, Coonrod J. 2008. GIS techniques for creating river terrain models for hydrodynamic modeling and flood inundation mapping. Environ Modell Softw 23(1011):1300-11.

Meybeck M, Moatar F. 2012. Daily variability of river concentrations and fluxes: indicators based on the segmentation of the rating curve. Hydrol Process 26:1188-207.

Moatar F, Meybeck M, Raymond S, Birgand F, Curie F. 2013. River flux uncertainties predicted by hydrological variability and riverine material behavior. Hydrol Process 27:3535-46. doi:10.1002/hyp.9464.

Montreuil O, Mérot P. 2006. Nitrogen removal in valley bottom wetlands: assessment in headwater catchments distributed throughout a large basin. J Environ Qual 35:2113-22.

Moussa R. 2009. Definition of new equivalent indices of HortonStrahler ratios for the derivation of the Geomorphological Instantaneous Unit Hydrograph. Water Resour Res 45:W09406. doi:10.1029/2008WR007330.

Munz M, Oswald SE, Schmidt C. 2011. Sand box experiments to evaluate the influence of subsurface temperature probe design on temperature based water flux calculation. Hydrol Earth Syst Sci 15(11):3495-510.

Newman BD, Osenbruck K, Aeschbach-Hertig W, Solomon DK, Cook P, Rozanski K, Kipfer R. 2010. Dating of 'young' groundwaters using environmental tracers: advantages, applications, and research needs. Isot Environ Health Stud 46(3):259-78.

Ocampo CJ, Oldham CE, Sivapalan M. 2006. Nitrate attenuation in agricultural catchments: shifting balances between transport and reaction. Water Resour Res 42:W01408. doi:10.1029/ 2004WR003773.
Oldham CE, Farrow DE, Peiffer S. 2013. A generalized Damköhler number for classifying material processing in hydrological systems. Hydrol Earth Syst Sci 17(3):1133-48.

Omernik JM. 1976. The influence of land use on stream nutrient levels. EPA Report 600/3-76-014, Washington, DC: USEPA, $105 \mathrm{pp}$

Pinay G, Clément J, Naiman RJ. 2002. Basic principles and ecological consequences of changing water regime for nitrogen cycling in fluvial systems. Environ Manag 30(4):481-91.

Pinay G, Gumiero B, Tabacchi E, Gimenez O, Planty-Tabacchi AM, Hefting MM, Burt TP, Black V, Nilsson C, Iordache V, Bureau F, Vought LM, Petts GE, Décamps H. 2007. Patterns of denitrification rates in European alluvial soils under various hydrological regimes. Freshw Biol 52:252-66.

Pirotti F, Tarolli P. 2010. Suitability of LiDAR point density and derived landform curvature maps for channel network extraction. Hydrol Process 24(9):1187-97.

Poggio L, Soille P. 2011 . A probabilistic approach to river network detection in digital elevation models. Catena 87(3):341-50.

Poudel DD, Lee T, Srinivasan R, Abbaspour K, Jeong CY. 2013. Assessment of seasonal and spatial variation of surface water quality, identification of factors associated with water quality variability, and the modeling of critical nonpoint source pollution areas in an agricultural watershed. J Soil Water Conserv 68(3):155-71.

Pourret O, Gruau G, Dia A, Davranche M, Molenat J. 2010. Colloidal control on the distribution of rare earth elements in shallow groundwaters. Aquat Geochem 16(1):31-59.

Ranalli AJ, Macalady DL. 2010. The importance of the riparian zone and in-stream processes in nitrate attenuation in undisturbed and agricultural watersheds-a review of the scientific literature. J Hydrol 389(3-4):406-15.

Rapinel S, Hubert-Moy L, Clément B, Nabucet J, Cudennec C. 2013. Ditches' network extraction and hydrogeomorphological characterization using LiDAR-derived DTM in wetlands. Hydrol Res. doi:10.216/nh.2013.121.

Reddy KR, Rao PSC, Jessup RE. 1982. The effect of carbon mineralization on denitrification kinetics in mineral and organic soils. Soil Sci Soc Am Proc 46:62-8.

Reddy KR, Patrick WH. 1984. Nitrogen transformation and loss in flooded soils and sediments. Crit Rev Environ Control 13(4):273-309.

Reilly TE, Plummer LN, Phillips PJ, Busenberg E. 1994. The use of simulation and multiple environmental tracers to quantify groundwater flow in a shallow aquifer. Water Reosur Res 34(2):421-33.

Rempe DM, Dietrich WE. 2014. A bottom-up control on freshbedrock topography under landscape. Proc Natl Acad Sci $111(18): 6576-81$.

Rockström J, Steffen W, Noone K, Persson A, Chapin SF, Lambin EF, Lenton TM, Scheffer M, Folke C, Schellnhuber HJ, Nykvist B, de Wit CA, Hughes T, van der Leeuw S, Rodhe H, Sörlins Snyder PK, Costanza R, Svedin U, Falkenmark M, Karlberg L, Corell RW, Fabry VJ, Hansen J, Walker B, Liverman D, Richardson K, Crutzen P, Foley JA. 2009. A safe operating space for humanity. Nature 46:472-5.

Rogan J, Chen DM. 2004. Remote sensing technology for mapping and monitoring land-cover and land-use change. Prog Plann 61:301-25.

Rose L, Krause S, Cassidy NJ. 2013. Capabilities and limitations of tracing spatial temperature patterns by fiber-optic dis- 
tributed temperature sensing. Water Resour Res 49(3):17415.

Sabater S, Butturini A, Clément JC, Burt TP, Dowrick D, Hefting M, Maître V, Pinay G, Postolache C, Rzepecki M, Sabater F. 2003. Nitrogen removal by riparian buffers under various $N$ loads along a European climatic gradient: patterns and factors of variation. Ecosystems 6:20-30.

Sahu M, Gu RR. 2009. Modeling the effects of riparian buffer zone and contour strips on stream water quality. Ecol Eng 35(8):1167-70.

Schaub M, Alewell C. 2009. Stable carbon isotopes as an indicator for soil degradation in an alpine environment (Urseren Valley, Switzerland). Rapid Commun Mass Spectrom 23(10):1499-507.

Schmidt C, Bayer-Raich M, Schirmer M. 2006. Characterization of spatial heterogeneity of groundwater-stream water interactions using multiple depth streambed temperature measurements at the reach scale. Hydrol Earth Sci 10(6):849-59.

Schmidt C, Conant B, Bayer-Raich M, Schirmer M. 2007. Evaluation and field-scale application of an analytical method to quantify groundwater discharge using mapped streambed temperatures. J Hydrol 347(3-4):292-307.

Schornberg C, Schmidt C, Kalbus E, Fleckenstein JH. 2010. Simulating the effects of geologic heterogeneity and transient boundary conditions on streambed temperatures-implications for temperature-based water flux calculations. Adv Water Resour 33(11):1309-19.

Sebilo M, Billen G, Grably M, Mariotti A. 2003. Isotopic composition of nitrate-nitrogen as a marker of riparian and benthic denitrification at the scale of the whole Seine River system. Biogeochemistry 63(1):35-51.

Sebilo M, Billen G, Mayer B, Billiou D, Grably M, Garnier J, Mariotti A. 2006. Assessing nitrification and denitrification in the Seine River and estuary using chemical and isotopic techniques. Ecosystems 9(4):564-77.

Seitzinger S, Harrison JA, Böhlke JK, Bouwman AF, Lowrance R, Peterson B, Tobias C, Van Drecht G. 2006. Denitrification across landscapes and waterscapes: a synthesis. Ecol Appl 16:2064-90.

Seitzinger SP. 1988. Denitrification in freshwater and coastal marine ecosystems: ecological and geochemical significance. Limnol Oceanogr 33:702-24.

Selker J, van de Giesen N, Westhoff M, Luxemburg W, Parlange MB. 2006. Fiber optic opens window on stream dynamics. Geophys Res Lett 33(24): doi:10.1029/2006GL027979.

Semaoune P, Sebilo M, Templier J, Derenne S. 2012. Is there any isotopic fractionation of nitrate associated with diffusion and advection? Environ Chem 9(2):158-62.

Smith MS, Tiedje JM. 1979. Phases of denitrification following oxygen depletion in soil. Soil Biol Biochem 11:261-7.

Strayer DL, Beighley RE, Thompson L, Brooks S, Nilsson C, Pinay G, Naiman RJ. 2003. Effects of land-cover change on stream ecosystems: roles of empirical models and scaling issues. Ecosystems 6:407-23.

Strohmeier S, Knorr KH, Reichert M, Frei S, Fleckenstein JH, Peiffer S, Matzner E. 2013. Concentrations and fluxes of dissolved organic carbon in runoff from a forested catchment: insights from high frequency measurements. Biogeosciences 10:905-16.

Sudicky EA, Frind EO. 1982. Contaminant transport in fractured porous-media-analytical solutions for a system of parallel fractures. Water Resour Res 18(6):1634-42.
Swanson TE, Cardenas MB. 2011. Ex-Stream: A MATLAB program for calculating fluid flux through sediment-water interfaces based on steady and transient temperature profiles. Comput Geosci 37(10):1664-9.

Tonina D, Buffington JM. 2007. Hyporheic exchange in gravel bed rivers with pool-riffle morphology: laboratory experiments and three-dimensional modelling. Water Resour Res 43(1): doi:10.1029/2005WR004328.

Trauth N, Schmidt C, Maier U, Vieweg M, Fleckenstein JH. 2013. Coupled 3D stream flow and hyporheic flow model under varying stream and ambient groundwater flow conditions in a pool-riffle system. Water Resour Res 49:1-17. doi:10.1002/ wrcr.20442.

Trauth N, Schmidt C, Vieweg M, Maier U, Fleckenstein JH. 2014. Hyporheic transport and biogeochemical reactions in poolriffle systems under varying ambient groundwater flow conditions. J Geophys Res Biogeosci 119: doi:10.1002/ 2013JG002586.

Udy JW, Bunn SE. 2001. Elevated delta N-15 values in aquatic plants from cleared catchments: why? Marine Freshw Res 52(3):347-51.

van der Velde Y, de Rooij GH, Rozemeijer JC, van Geer FC, Broers HP. 2010. Nitrate response of a lowland catchment: on the relation between stream concentration and travel time distribution dynamics. Water Resour Res 46: doi:10.1029/ 2010WR009105.

van der Velde Y, Torfs PJJF, van der Zee SE, Uijlenhoet R. 2012. Quantifying catchment-scale mixing and its effect on timevarying travel time distributions. Water Resour Res 48: doi:10. 1029/2011WR011310.

Viaud V, Caubel V, Grimaldi C, Baudry J, Mérot P. 2001. The influence of hedgerow systems on water and pollutant fluxes: from the local to the catchment scale. Hedgerows of the world: their ecological functions in different landscapes. Birmingham: International Association of Landscape Ecology.

Vidon P, Allan C, Burns D, Duval TP, Gurwick N, Inamdar S, Lowrance R, Okay J, Scott D, Sebestyen S. 2010. Hot spots and hot moments in riparian zones: potential for improved water quality management. J Am Water Resour Assoc 46(2):278-98.

Vidon P, Hill AR. 2004a. Denitrification and patterns of electron donors and acceptors in eight riparian zones with contrasting hydrogeology. Biogeochemistry 71(2):259-83.

Vidon P, Hill AR. 2004b. Landscape controls on nitrate removal in stream riparian zones. Water Resour Res 40(3): doi:10. 1029/2003WR002473.

Vitousek PM, Mooney HA, Lubchenco J, Melillo JM. 1997. Human domination of earth's ecosystems. Science 277(494): 494-9.

Waugh DW, Hall TM, Haine TWN. 2003. Relationships among tracer ages. J Geophys Res Oceans 108(C5): Article Number 3138.

Werbrouck I, Antrop M, Van Eetvelde V, Stal C, De Maeyer P, Bats M, Bourgeois J, Court-Picon M, Crombe P, De Reu J, De Smedt P, Finke PA, Van Meirvenne M, Verniers J, Zwertvaegher A. 2011. Digital elevation model generation for historical landscape analysis based on LiDAR data, a case study in Flanders (Belgium). Expert Syst Appl 38(7):8178-85.

Winterdahl M, Futter M, Köhler S, Laudon H, Seibert J, Bishop K. 2011. Riparian soil temperature modifies relationship between flow and organic carbon concentration in a boreal stream. Water Resour Res 47: W08532, doi:10.1029/ 2010 WR010235. 
Winterdahl M, Erlandsson M, Futter MN, Weyhenmeyer GA, Bishop K. 2014. Intra-annual variability of organic carbon concentrations in running waters: drivers along a climatic gradient. Global Biogeochem Cycles 28(4):451-64. doi:10. 1002/2013GB004770.

Whitehead PG, Wilson EJ, Butterfield D. 1998. A semi-distributed Integrated Nitrogen model for multiple source assessment in Catchments (INCA): part I-model structure and process equations. Sci Total Environ 210(1-6):547-58.

Wynn JG, Harden JW, Fries TL. 2006. Stable carbon isotope depth profiles and soil organic carbon dynamics in the lower Mississippi Basin. Geoderma 131(1-2):89-109.
Zarnetske JP, Haggerty R, Wondzell SM, Baker MA. 2011. Dynamics of nitrate production and removal as a function of residence time in the hyporheic zone. J Geophys Res 116:G01025. doi:10.1029/2010JG001356.

Zarnetske JP, Haggerty R, Wondzell SM, Bokil VA, GonzalezPinzon R. 2012. Coupled transport and reaction kinetics control the nitrate source-sink function of hyporheic zones. Water Resour Res doi:10.1029/2012WR013291.

Zarnetske JP, Haggerty R, Wondzell SM, Bokil VA, GonzalezPinzon R. 2012b. Coupled transport and reaction kinetics control the nitrate source-sink function of hyporheic zones. Water Resour Res W11508 doi:10.1029/2012WR011894. 